\title{
КУЛЬТУРА - ЛЮДИНА - ФІЛОСОФІЯ
}

\section{Т.А. Хорольська}

У наш час, коли перед людством постає ціла низка глобальних проблем, драматизм яких полягає у тому, що вони потребують для свого вирішення спільних, узгоджених зусиль усіх народів, проблеми культури набувають небувалої актуальності та гостроти. За спроби вирішити ï теоретична думка стикається з цілою сукупністю незвичних і традиційних філософських проблем, як-то: поняття і сутність культури; культура і діяльність; культура і розвиток людини; культура і історія; культура і спосіб життя; культура і політика та інші. Багато неусталеного і невирішеного серед них і в теорії, і в методології часто заважає більш ефективному здійсненню культурної політики тими або іншими народами, державами. Окремі з вище перерахованих питань і будуть предметом розмислів у даній статті. При цьому слід одразу ж зауважити, що повторюваність звернення дослідників до одних і тих же питань не слід розглядати як просте копіювання або пряме підлаштування під уже відоме дослідження. Адже суть подібних досліджень полягає в з'ясуванні того, що є відмінним, повторюваним, загальним і в теорії, і в методології на кожному наступному кроці пізнання культури.

Так, на сучасному етапі пізнання проблем культури найбільш ефективною слід визнати синергетичну методологію, оскільки культура повинна бути віднесена до розряду складних самоорганізованих об'єктів-систем. Певним чином остання успадковує системно-порівняльний аналіз явищ і процесів культури з виділенням типологічного, загального і особливого в них, повторюваного та неповторного, підносячи тим самим їх дослідження на якісно новий рівень.

Загальновідомо, що через свою багатоукладність культура є об'є-

Актуальні проблеми духовності 
ктом дослідження багатьох наук. Однак у той же час вона $є$ цілісністю, причому такою, що потребує до себе особливого підходу, яким сьогодні і є синергетичний підхід, що забезпечує значно більше можливостей для аналізу існування і розвитку культури як у їі минулому, так і у багатогранному сьогоденні.

Культура - багаторівнева система, й завдання науки і філософії полягають у тому, щоб осмислити її і на кожному рівні, й у цілому, в основних закономірностях та тенденціях притаманних тому або іншому історичному періоду існування та розвитку. Відомо, що терміну «культура» у різних науках надається перш за все функціональний, а не онтологічний зміст, пропонуються такі визначення культури, які не рідко взаємно виключають один одного [1].

Ми розуміємо культуру як певну форму творчої діяльності людини, як певну форму суспільно-історичної свідомості і духовного розвитку людської особистості, як процес виробництва, збереження та сприйняття матеріальних та духовних цінностей, що відіграють надзвичайно важливу духовно-перетворюючу роль у житті людини і суспільства. Таке розуміння культури дає нам можливість виокремити у якості провідних ті проблеми і аспекти, які визначать їі сутність. До таких слід віднести: 1) співвідношення соціально-об'єктивного і суб'єктивноособистісного у творчій діяльності суб'єктів культури; 2) співвідношення ціннісно-нормативної, смислової та творчої характеристики життєдіяльності людини; 3) історичну активну творчу діяльність людини; 4) розвиток самої людини включеної у живу тканину творчої життєдіяльності; 5) співпадання розвитку, творення культури з творенням і розвитком особистості у залежності від яких, на наш погляд, і можуть мати місце розбіжності розуміння змісту культури.

Культура, відтак, є творчою, будівничою діяльністю людини як минулою, втіленою у цінностях, традиціях, смислах, нормах і т.ін., так і актуальною, теперішньою, що грунтується на розпредметненні цінностей, ідеалів і норм творчими здібностями людських індивідів. Культура, здійснюючи міцний вплив на хід сучасного світового розвитку і сама, у свою чергу, відчуває не менш сильний вплив на себе з боку цього розвитку.

Одним із суттєвих чинників, що визначає розвиток культури у наш час $є$ процес глобалізації суспільного життя, руйнація просторово-територіальних і часових бар'єрів між суб'єктами культури сучасними засобами комунікації та інформації, які, з одного боку, створюють передумови для максимального посилення їх взаємозв'язків, а з іншого, - передумови для «розмивання» накопиченого культурно-істори- 
чного досвіду кожним з них.

Самі по собі процеси глобалізації та пов'язана з ними передбачувана взаємодія культур $\epsilon$ процесами об'єктивними і у кінцевому рахунку є умовою розвитку кожного конкретно-історичного типу культури. Однак у трактуванні та оцінці значення цих процесів стикаються різні соціально-філософські і культурологічні позиції. А тим часом існує нагальна потреба напрацювання більш менш єдиної стратегії їх рішення, яка, з одного боку, враховувала б ці відмінності і навіть розбіжності, з іншого, - покладалась на таке розуміння сучасного культурного розвитку, яке могло б стати загальною базою порозуміння суб'єктів культури, що знаходяться, по-перше, на різних рівнях соціального розвитку, а по-друге, відрізняються характером духовних процесів, життєвими укладами, стилем та способами життя. Адже саме поняття життя $\epsilon$ тим необхідним елементом культурного цілого, яке характеризує витоки людського залучення у культуру, спосіб включення індивіда до культури, стан культурності. 3 іншого боку, культура, будучи сама впорядкованою за визначенням, впорядковує людське життя, оскільки логіка життя і логіка культури хоч і пов'язані тісно між собою, тим не менше логіка життя не $є$ логікою культури, а логіка культури не $\epsilon$ логікою життя. Однак онтологічна потреба людини бути людиною зумовлює утворення онтологічної цілісності життя і культури, у просторі якої втілюються всі людські наміри і смисли, істинність і повнота буття.

У вищевикладеній ситуації кожна із означених тенденцій може виявитися своєю протилежністю, що ми і маємо можливість спостерігати сьогодні у культурному бутті народів на пострадянському просторі. Намагання окремих колишніх радянських республік довести до крайнощів культурну самобутність загрожує одним - переростанням у самоусобленість, другим - своєрідним культурним ізоляціонізмом, третім - культурною винятковістю. 3 іншого боку, передбачувані процесами глобалізації взаємодія та взаємне культурне збагачення обертаються на ділі для окремих народів культурною експансією. Замість глобальних рівноправних зв'язків, у такому випадку, ми маємо можливість спостерігати глобальне нищення і національної, i загальнолюдської культури. Так, скажімо, зовнішнє втручання у самостійне і своєрідне вирішення тими або іншими народами своїх внутрішньокультурних справ, або насадження за допомогою сучасних засобів інформації чужих духовних та життєвих стандартів можуть мати непоправні негативні глобальні наслідки для людства в цілому. У цьому нас переконують безліч фактів так званих «мирних», духовних, еконо- 
мічних та військових експансій, виголошених та невиголошених війн XX-XXI століть, які загрожують людству непоправними втратами у соціально-культурному розвитку та розвитку особистості.

Тим не менше, не $є$ виключенням у сучасних дослідженнях соціально-культурного розвитку окремих народів те, що культурний вплив однієї національної культури на іншу, вплив одного суспільного діяча на іншого тлумачаться як чисто формальні співпадання на основі зовнішнього, випадкового уподібнення, простого наслідування, а не по суті.

Взаємовплив культур - це перш за все сприйняття суб'єктами культури певних загально значимих культурних смислів, ідей, життєвотворчих принципів. I у разі, якщо ці ідеї та принципи історично i гуманістично виправдані, то процес їх культурного сприйняття буде творчим, а значить виключатиме нівелювання тих або інших суб'єктів культури. Більше того, такі взаємовпливи сприяють зміцненню зв'язків особистості з власним національним середовищем, власною вітчиЗняною культурою й історією. Головне при цьому полягає не у тому, щоб дослідженнями зафіксувати факти зв'язків і взаємодій культур, а у з'ясуванні їх істинної значимості для розгортання світового історико-культурного процесу, визначення місця і ролі особистості, окремих країн і народів у ньому. Скажімо, така культурна подія епохального значення як створення Кирилом та Мефодієм слов'янської азбуки відіграла видатну роль у культурній долі багатьох слов'янських народів, включаючи і києво-руський. На жаль, є чимало прикладів із соціально-культурного життя тих же слов'янських народів, які мають ефект впливу протилежного значення, що суттєво відбивається на процесі сучасного національно-культурного відродження.

Зближення та порозуміння культур стає нормою співжиття народів як суб'єктів культури за умови рівноправності, партнерства та творчого співробітництва, безкорисливості відношень, обміну культурним досвідом, недоторканості самобутності тієї або іншої культури, так званого «культурного маркетингу», інтернаціональної зовнішньої культурної політики з її дипломатичними та політичними чинниками. Саме завдяки такому «культурному маркетингу» зовнішніх культурних політик кожен суб'єкт культури дістає більш менш раціональний захист та інструмент сприяння розвитку самобутньої національної культури. Тим більше, що у сучасній цивілізації культура визначається не засадничими поняттями життя і діяльності людини, а поняттями «циркуляції і акумуляції можливостей» (П. Козловський) та актуалізацією їх використання. Тобто йдеться про проблеми плюралізації і інтеграції 
культури та про ту напругу, яка виникає між життям, як своєрідним буттєвісним багатоманіттям історично-культурних субєктів та нормативністю культури у процесі глобалізації, між національними культурами та, скажімо, нормативністю прав людини з їх обов'язковістю для будь-якої культури, а не лише західної. Адже саме з ідеєю і уявленнями про права людини як її гідність та «неоціненність суб'єктності» (Гегель), на наш погляд, і можлива загальнолюдська культура у ii гуманістичному прояві і змісті. Культурний же релятивізм стосовно такої універсалії як права людини завжди повинен розглядатися як позиція панування, оскільки він не оцінює людей різних культур як рівноправних і водночас самобутніх.

Аналізуючи сутність культури, необхідно ставити, на наш погляд, більший наголос на тому, що вона не лише створюється людиною, а й заради людини, що це специфічно людський спосіб буття. Така традиція має глибоке коріння, що сягає ще античності. Людина засобами виховання культивує у собі певні навички, звички, вміння, здібності і переконання. У культурі відбувається індивідуальне відтворення людини. Вона переживає своє ніби друге народження. Тому культуру у цьому контексті можна визначити і визнати способом самотворення i самовідтворення, розвитку і саморозвитку особистості, способом самоусвідомлення і ставлення до себе самої та інших. Вона покликана стати контекстом, живою тканиною смислів, з якими співвідносить себе людська особистість, засобом інтеграції індивідуальних вчинків і поведінки у так звану персональну культурну біографію та культурну біографію народу, людства. Відтак, оформлення культурної біографії повинно відбуватися перш за все у сфері освіти і виховання. Не випадково сформувалось у свій час уявлення про культуру як сферу виховної та просвітницької діяльності у самому широкому значенні цього слова, яка здійснюється певними групами людей та соціальних інституцій. Остання теоретично включає в себе процес дослідження, вивчення, збереження, розповсюдження та засвоєння цінностей культури, залучення до них різних верств населення через різні види навчання та просвіти, діяльність закладів культури і т. ін. Але ж поставимо питання: чи може сучасна система освіти, у якій навчальні програми принципово змінюються майже щорічно, від Міністра до Міністра, оптимізувати вирішення питання формування культурної біографії особистості? Існуючі факти непорозумінь між викладачами і учнями, між батьками і дітьми, особистістю і суспільством свідчать про те, що у системі комунікативних дій названі суб'єкти орієнтуються на різні взірці та життєво значимі цінності, без врахування загальнокультурної тканини 
смислів та ідеалів. Приділення більшої уваги вивченню природознавчих дисциплін, результати яких доволі швидко старіють, на всіх рівнях освіти повинне, на наш погляд, бути зменшеним на користь дисциплін більш орієнтованих на культуру та засвоєння $\dddot{1}$ принципової першозначимості для розуміння тенденцій розвитку людини і суспільства, для усвідомлення особистістю більших можливостей формування усіх сфер людського буття засобами культури.

Якщо ж втрачається загальнокультурна тканина смислів і значень, то культурна орієнтація для окремої людини стає майже неможливою. 3 іншого боку, індивідуальні події людської життєдіяльності та ï переживання не можуть не бути включеними до смислової органіки кожного етапу існування і розвитку культури як культурного надбання певного покоління, репрезентованого індивідуальністю. Більше того, культурна ідентичність (немає значення - чи то особистість, чи нація, народ) повинна бути культурно динамічною, спроможною до культурних змін, поза як може наступити «тиск ідентичності всезагального» (Т.Адорно), примус до культурної псевдо узгодженості. Іншими словами, здійснення соціально-культурної комунікації вимагає від ідентичностей постійного самовдосконалення, чітких думок, ідеалів і цінностей, виразних здібностей суб'єктів культури до культурних змін та особливого піднесення їх моральної «культурності», до того, що у свій час Гегель називав «ідентичністю ідентичного і неідентичного», «буттям-з-собою-і-іншим», до поєднання ідентичності з утриманням рівності самій собі. А відтак, не турбота про людину, і не відмова від неї є кінцевою метою культури, а постійне створення умов для вдосконалення людини. Між іншим, у цьому контексті доречним буде згадати біблійний вираз: «Кому багато дається, з того багато i запитується», який слід визнати справедливим не лише для індивідів, а й для суспільства, людства. Джерелом культурного розвитку людей, зростання їх духовних запитів та потреб, їх підвищеної зацікавленості у самозбагаченні своєї індивідуальності була і залишається активність, пряма і безпосередня включеність індивідів у соціальнокультурний процес як системну цілісність у всій її складності і структурі. Поза власною активністю залучення до соціально-культурного процесу буде носити формальний характер, формальне засвоєння і виконання особистістю норм і регламентацій культури, що призведе до чисто пасивної та споживацької «насиченості» культурними благами, до людини «в культурі», а не до культурної людини. «Розгортання» ж запитів індивідів на культуру, у такому випадку, супроводжується не вдосконаленням та духовним самозбагаченням особистості, а навпаки, 
граничним звуженням їі потенційних творчих можливостей, збіднінням внутрішнього духовного світу. Саме таке людське псевдо «культивування» призводило у недалекому минулому родючі землі до спустошення, до забруднення річок та водоймищ, атмосфери, до такої нібито доцільної діяльності, від якої тхне нерозумністю, недоцільністю та стихією і хаосом. Недопущення людиною подібного свавілля можливе за умови усвідомлення таких складових культуротворення як свобода і відповідальність, здібність людини визначати міру своєї власної відповідальності за культуру як специфічно людського способу буття, у якому ціннісно-добродійне співпадає з істиною та красою, індивідуальне з загальнолюдським, об'єктивне з суб'єктивним.

Таким чином, неприйнятними тенденціями, що склалися у філософії стосовно розуміння формування ідентичної культурної біографіï є як тенденція відокремлення індивіда від розвитку всезагальності культури (Ф.Ніцше), так і тенденція розчинення індивідуальної культурної біографії у соціально-культурному середовищі (Л. Фейєрбах, K. Маркс).

Розгляд культури у особистісному аспекті, її орієнтації на розвиток людської особистості, орієнтації на «вічні цінності» Істини, Добра і Краси засвідчує своєрідність відображення ідеалів, взірців і смислів, у тому числі і у політичній культурі. Даний аспект розгляду культури стає надто актуальним в умовах тиску на людину багатьох негативних соціально-політичних обставин нашого життя, в умовах дефіциту політичної культури, політичної пасивності певної частини населення i ін. Як у свій час зазначалося в одному із німецьких часописів термін «політична культура» відноситься до тих понять, значення яких зростає відповідно до того, наскільки частішими стають скарги на занепад політичних уподобань. Цей термін вживається тим частіше, чим більше виникає підстав скаржитися на недостатньо глибоке вкорінення справедливості того або іншого соціально-політичного ладу та інших політичних цінностей у свідомості громадян [2]. Відтак, поняттю «політичні цінності» як компоненту політичної культури притаманна стійка орієнтація свідомості на оприявлення відношення до соціальнополітичного ладу, до політичних та правових інституцій, що функціонують у суспільстві. Тому політичну культуру можна було б визначити як суму соціально усвідомлених і глибоко сприйнятих цінностей та переконань, які пронизують політичну діяльність суб'єктів того або іншого суспільства, включаючи його мікрорівень (особистість) та макрорівень (політична система).

Однак політична культура не зводиться лише до політичної свідо- 
мості, а закономірно передбачає перетворення останньої у політичні діï. Результативність таких дій передбачає їх оцінку з точки зору втілення інтересів людських індивідів, певних груп і верств населення та викладення у вигляді політичних норм поведінки політичних діячів, партій, держави та суспільних організацій. При цьому політична практика, як структурний елемент політичної культури, часто і густо не $\epsilon$ адекватністю політичним цінностям як ідеалам культури, що у решті решт і викликає кризу політичної культури та невдоволення людини і суспільства. Характерним прикладом у цьому контексті є стан, сутність та функціонування політичної культури нашого суспільства.

Політична культура, отже, є виразником якості та впорядкованості соціально-політичного життя людей, поза яким не може знаходитись жодна свідома верства населення, жодне соціальне утворення, жодна особистість. Політична практика вилучення з цього процесу будь-кого з них, а тим більше національної системи освіти, означатиме позбавлення певних верств населення активної участі у впорядкуванні соціально-політичного життя засобами політичної культури. Але ж, на наш погляд, суттєвою помилкою політики і політиків є думка про те, що система освіти - це менш важливий чинник формування політичної культури особистості і суспільства, ніж, скажімо, партії, системи засобів інформації та реальні політичні обставини, потреба у політичній культурі як об'єктивних чинниках. Тим паче, що у процесі вивчення різних наук відмічаються різні аспекти політичної культури як: а) різновиду інтегральних культурних цінностей; б) певного способу, форми і рівня духовно-практичної діяльності та відношень індивідів і суспільства; в) виразу, закріплення та реалізації докорінних інтересів певних верств населення, спільнот та особистості; г) сукупності певних політичних поглядів, цінностей, знань, вмінь і навичок; д) активної участі громадян у суспільно-політичному житті; $\epsilon$ ) забезпечення функціонування політичних і соціальних інституцій, норм, традицій і т. ін.; ж) міри практичної реалізації людських інтересів та політичних ідеалів, що проголошують політичні партії, держава, політичні діячі; з) оцінка та співвіднесеність наявних політичної свідомості та політичної діяльності з цілісністю культури та моралі.

\section{1 Бібліографія}

[1] Див.: Маркарян Г.С. Очерки теории культуры; Межуев В.M. Культура и история; Давидович B.E., Жданов Ю.А. Сущность 
культуры; Злобин Н.C. Культура и духовность; Моль А. Социодинамика культуры; Козловски П. Культура постмодерна; Быстриuкий E.K. Феномен личности: мировоззрение, культура, бытие; ШІиккарук B.I. Поняття культури. Філософські аспекти // Феномен української культури: методологічні засади осмислення; Табаиковсъкий В.Г. Антропокультурне та соціокультурне у людськім світовідношенні // Філософська і соціологічна думка. - 1996. № $3-4$ і ін.

[2] Див.: Die Politische Meinung. - 1981. - № 194.

[3] Бом Д. Науки и духовность: необходимость изменений в культуре // Человек. - 1993. - № 1.

[4] Бытие человека в культуре (Опыт онтологического подхода).K., 1994.

[5] Петров М.К. Социально-культурные основания развития современной науки. - М.: Наука, 1992. 